\title{
Benign bone tumors subperiosteal on the talar neck resected anthroscopically: case reports
}

\author{
Tumores ósseos benignos subperiosteais do colo do tálus ressecados artroscopicamente: \\ relatos de caso
}

\author{
Marcelo Pires Prado ${ }^{1}$, Alberto Abussamara Moreira Mendes², Daniel Tassetto Amodio
}

\begin{abstract}
Two cases of benign chondral tumors of the talar neck region (an osteoid osteoma and a chondroblastoma) were described. Because of their specific, unusual site they could be resected by arthroscopy. The imaging aspects, incidence in foot bones and possibilities of treatment were discussed, and a literature review is presented.
\end{abstract}

Keywords: Chondroblastoma/surgery; Bone neoplasms/surgery; Osteoma, osteoid/surgery; Talus/surgery; Arthroscopy; Case reports

\section{RESUMO}

Dois casos de tumores condrais benignos na região do colo do tálus (um osteoma osteoide e um condroblastoma) foram descritos. Puderam ser resectados por artroscopia devido à localização específica e pouco comum. Discutiram-se os aspectos sobre exames de imagens, a incidência em ossos do pé e as possibilidades de tratamento, além de apresentar uma revisão da literatura.

Descritores: Condroblastoma/cirurgia; Neoplasias ósseas/ cirurgia; Osteoma osteoide/cirurgia; Tálus/cirurgia; Artroscopia; Relatos de casos

\section{INTRODUCTION}

Arthroscopy has been used for treating many pathological conditions of the ankle joint. The authors showed relatively uncommon causes of ankle pain: an osteoid osteoma and a chondroblastoma of the talar neck (a rare site) $)^{(1)}$, in the subperiosteum, and with no common radiographic changes related to these lesions ${ }^{(2)}$. Due to the particular site, the resection could be performed by arthroscopy, with complete excision of the lesions and resolution of the patients' complaints.
The authors described two cases of young male patients suffering severe anterior ankle pain associated with previous traumas, and treated as ankle sprains and anterior impingement syndromes without resolution.

The radiographs showed no significant changes; however, upon magnetic resonance imaging (MRI), there were localized lesions at the talar neck, surrounded by a thick synovial membrane. Both patients underwent ankle arthroscopy and the removal of associated synovitis and entire nidus resection. The pain disappeared in both patients immediately after surgery, and late results were excellent.

\section{CASE 1}

F.S.M., a 37 year-old male patient suffered from severe left ankle pain, with a giving way sensation for over one year. The pain increased with normal daily activities, and at night, slightly relieved with non-steroidal antiinflammatory drugs. Upon physical examination he complained of severe tenderness in the anteromedial aspect of his left ankle with moderate effusion, without instability as seen in the anterior drawer test. Imaging investigation with MRI showed an important anterior medial synovitis, with an irregularity on the dorsal medial cortex of the talar neck (Figure 1). He was treated by hindfoot elevation and physiotherapy for six months with no pain resolution, and was submitted to another MRI, which showed a round lesion on the dorsal medial aspect of the talar neck. He underwent ankle arthroscopy to resect synovitis and remove a flesh-colored round lesion, $8 \mathrm{~mm}$ in diameter that was resting in the cortical bed (Figure 2). The pathological

\footnotetext{
'Master's degree; Orthopedic physician at Hospital Israelita Albert Einstein - HIAE, São Paulo (SP), Brazil.

${ }^{2} \mathrm{MD}$; Orthopedic at Hospital Israelita Albert Einstein - HIAE, São Paulo (SP), Brazil.

${ }^{3} \mathrm{MD}$; Orthopedic at Hospital Israelita Albert Einstein - HIAE, São Paulo (SP), Brazil.

Corresponding author: Marcelo Pires Prado - Avenida Albert Einstein, 627 - Conj. 1204 - Morumbi - CEP 05651-901 - São Paulo (SP), Brasil - Tel.: 2151-5320 - E-mail: mpprado@einstein.br

Received: Oct 01, 2009 - Accepted: Jul 15, 2010
} 
study revealed a chondroblastoma of the talar neck. After surgery the pain completely disappeared, and the patient returned to pre-lesion status after four weeks of rehabilitation. Presently he is in the third postoperative year, with no complaints or physical limitations.

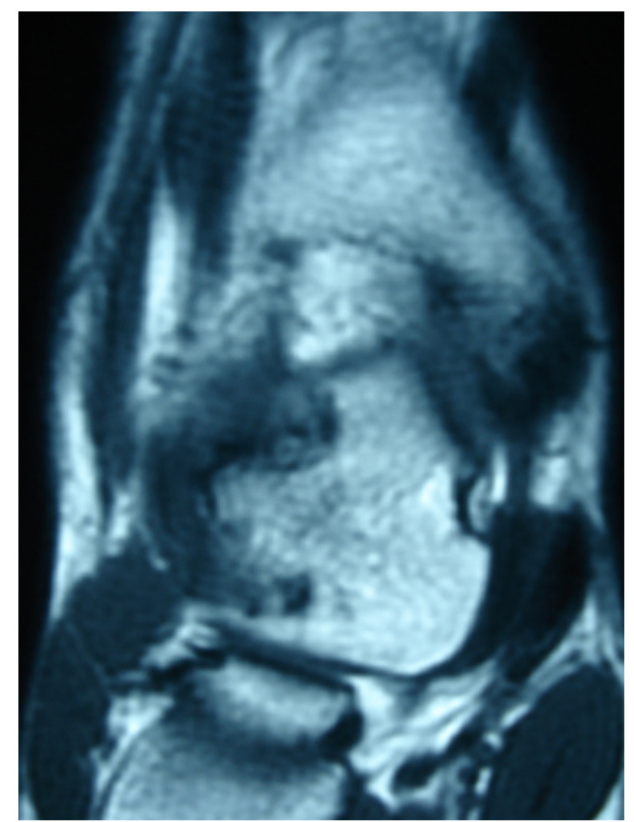

Figure 1. Case 1: MR image with talar neck irregularity

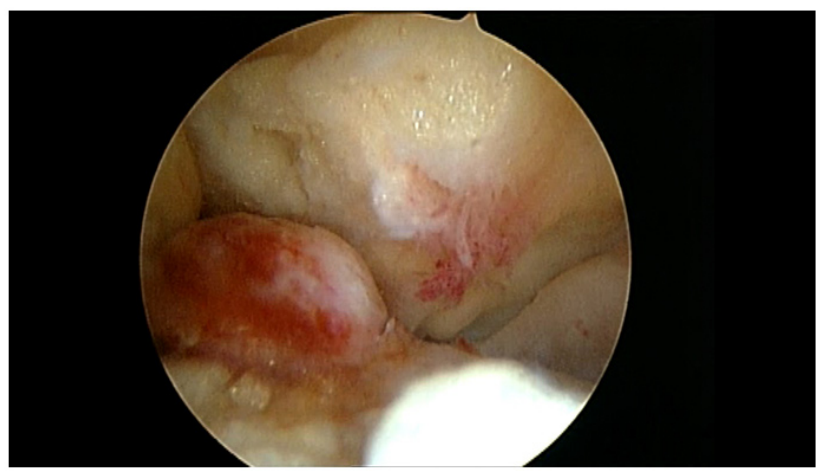

Figure 2. Case 1: Arthroscopy image of talar neck lesion

\section{CASE 2}

D.R.C., 21 year-old male patient had been suffering with right ankle pain for over 5 months. He had a history of an ankle sprain 18 months prior to the onset of symptoms, treated with rest, ice and restriction of physical activities for one month. Pain severity increased and, during the first visit, he had severe anterior lateral pain on his right ankle joint, with tenderness on palpation, a moderate ankle effusion, and restricted range of motion due to intense pain. The radiography revealed an irregularity on the dorsal aspect of the talar neck (Figure 3), and the MRI showed exostosis and synovitis in the same region, with inflammatory changes on the talar neck (Figure 4). He underwent ankle arthroscopy to remove the hypertrophic synovial tissue, and to remove exostosis. During the procedure a round red mass measuring $5 \mathrm{~mm}$ in diameter was found in the exostosis region (Figure 5), which was removed and its bed curetted (Figure 6). The pathological study revealed a benign tumor characterized by bone trabeculae surrounded by osteoblasts and osteoclasts, in a fibrovascular tissue structure, with bone sclerosis on its periphery, confirming the diagnosis of osteoid osteoma (Figure 7). The patient had no pain during the early postoperative period, and, after three weeks of physiotherapy, returned to his regular sports activities, without symptoms. On the recent threeyear follow-up visit, he had no complaints.

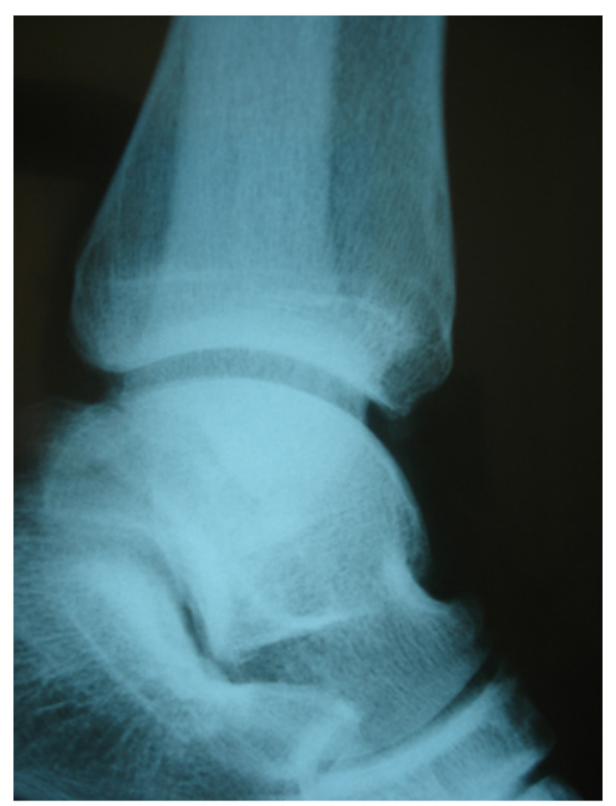

Figure 3. Case 2: Radiographic image

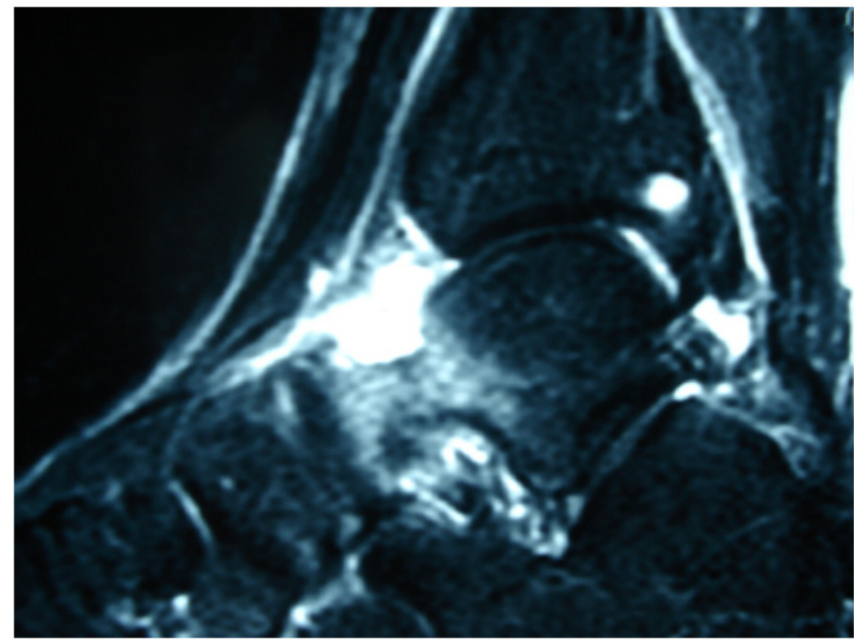

Figure 4. Case 2: Magnetic resonance image (MRI) 


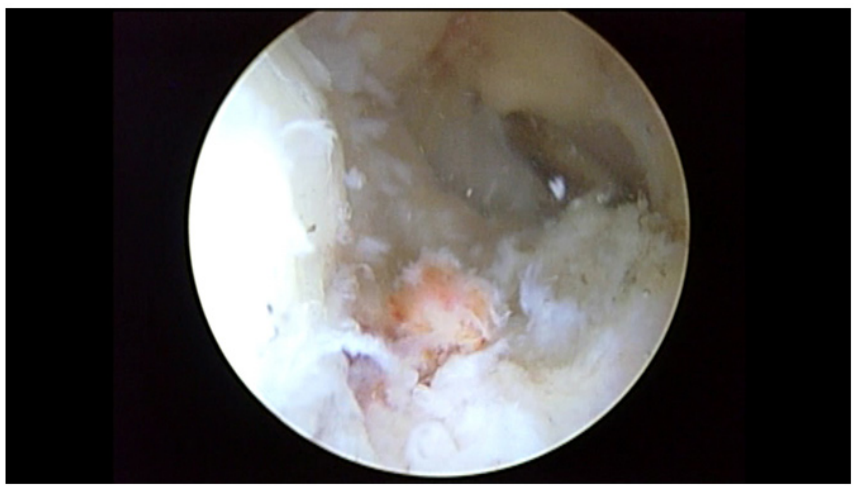

Figure 5. Case 2: Arthroscopic aspect

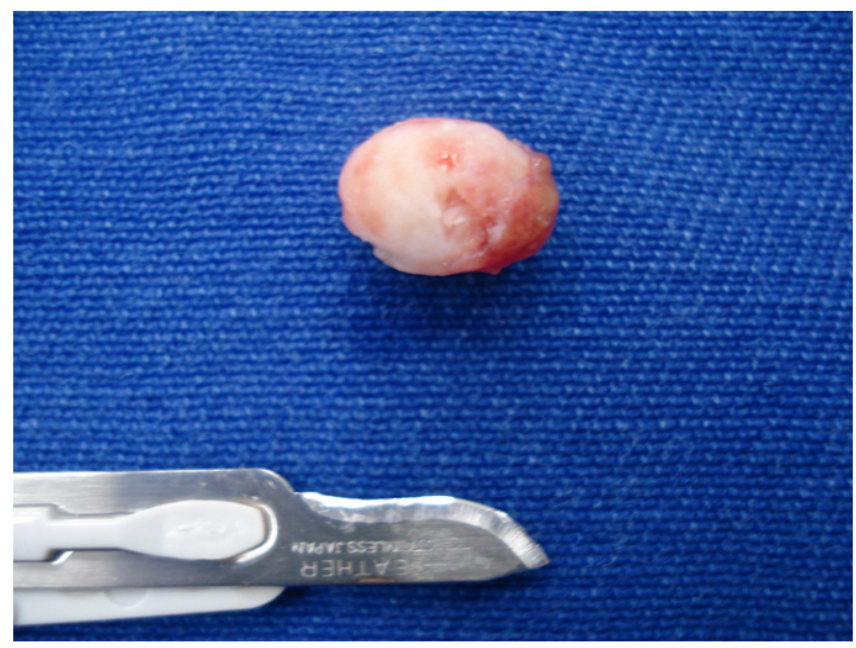

Figure 6. Case 2: Resected lesion

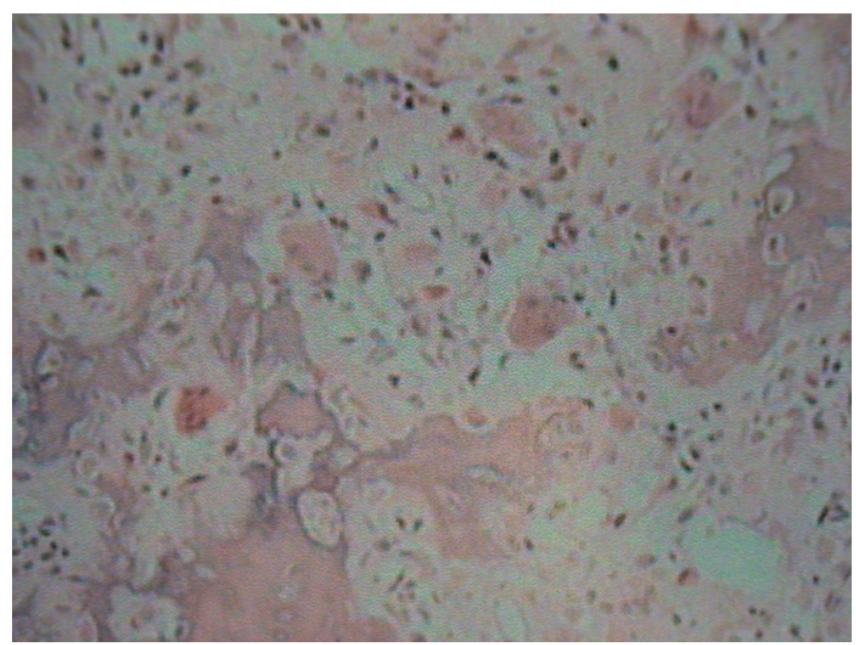

Figure 7. Case 2: Pathological image

\section{DISCUSSION}

Osteoid osteomas are benign osteoid-forming lesions that are not uncommon in tarsal bones and from 2 to $11 \%$ affect the foot, with the talus being the most common location. They are small, very painful tumors that classically appear in the radiographs as central osteolitic lesions (called nidus) with a surrounding dense osteoblastic reaction. The typical presentation is well localized pain that is more severe at night, relieved by aspirin and other salicilates and prostaglandin inhibitors. The most frequent site is cortex of the affected bone; however it can occur in the subperiosteal and endosteal regions. On these sites the radiographic characteristic of typical bone sclerosis is not always present. Treatment is symptomatic, in order to relieve pain, as it can became asymptomatic in 1.5 to 2 years. If pain is not well controlled, a surgical resection is indicated. Histology reveals a nidus composed of thick, vascular bars of osteoblastic tissue surrounded by a thin zone of vascular fibrous tissue and by a dense margin of mature reactive sclerotic bone.

Chondroblastoma is a rare cartilagenous benign tumor having a typical histological appearance of closely compacted polyhedral cells, with focal areas of calcification and necrosis without mitotic figures. Clinically it is similar to an osteoid osteoma, with pain is relieved by salicilates. When it is located near a joint there is effusion and sometimes mobility limitation. This lesion occurs in adolescence, more common in male, and the most frequent sites are epiphyses of the proximal humerus, distal femur and proximal tibia $^{(1,3)}$. Nonetheless, there are some references of chondroblastoma affecting the talus ${ }^{(4-8)}$.

The diagnosis of these lesions, in uncommon sites, is often delayed for months or even years, and are often treated as ankle sprains ${ }^{(2,9)}$.

MRI is an important tool for diagnosing pathologic conditions of the hindfoot, but the computed tomography (CT) is the best modality to identify and find the characteristic nidus of these lesions ${ }^{(10)}$.

These cases are significant because they highlight the diagnostic possibility of benign chondral tumors (osteoid osteoma and chondroblastoma) as causes of chronic ankle pain. Moreover, considering their uncommon site, they are frequently diagnosed without the typical findings of sclerosis in radiographs ${ }^{(11)}$.

The site of these specific lesions (superficial and intra-articular) allows them to be arthroscopically resected, as demonstrated by other authors ${ }^{(12-14)}$.

\section{REFERENCES}

1. Tachdjian's pediatric orthopeadic. 2nd ed. Vol. 2. Philadelphia: WB. Saunders; 1990. Benign chondroblastoma; p. 1200-3.

2. Francesco B, Andrea LA, Vincenzo S. Intra-articular osteoid osteoma of the lower extremity: diagnostic problems. Foot Ankle Int. 2002;23(3):264-7.

3. Knackfuss IG, Rosembaum S, Giordano V, Metsavath L, Ferreira Neto M, Giordano M. Condroblastoma do navicular: relato de caso. Rev Bras Ortop. 2003;38(5):301-4. 
4. Breck LW, Emmett JE. Chondroblastoma of the talus: a case report. Clin Orthop. 1956;7:132-5.

5. Moore TM, Roe JB, Harvey JP Jr. Chondroblastoma of the talus. J Bone Joint Surg Am. 1977;59(6):830-1.

6. Fink BR, Temple HT, Chiricosta FM, Mizel MS, Murphey MD. Chondroblastoma of the foot. Foot Ankle Int. 1997;18(4):236-42.

7. Ochsner PE, von Hochstetter AR, Hilfiker B. Chondroblastoma of the talus: natural development after 9.5 years. Case report. Arch Orthop Trauma Surg. 1988;107(2):122-5.

8. Yu GV, Sellers CS. Chondroblastoma of the talus. J Foot Ankle Surg. 1996;35(1):72-7.

9. van Horn JR, Karthaus RP. Epiphyseal osteoid osteoma. Two case reports. Acta Orthop Scand. 1989;60(5):625-7.
10. Monroe MT, Manoli A 2nd. Osteoid osteoma of the lateral talar process presenting as a chronic sprained ankle. Foot Ankle Int. 1999;20(7):461-3.

11. Corbett JM, Wilde AH, McCormack LJ, Evarts CM. Intra-articular osteoid osteoma: a diagnostic problem. Clin Orthop Relat Res. 1975; (98):225-30.

12. Yercan HS, Okcu G, Ozalp T, Osiç U. Arthroscopic removal of the osteoid osteoma on the neck of the talus. Knee Surg Sports Traumatol Arthrosc. 2003;12(3):246-9.

13. Gunes T, Erdem M, Sen C, Bilen E, Yeniel K. Arthroscopic removal of a subperiosteal osteoid osteoma of the talus. J Am Podiatr Med Assoc. 2007;97(3):238-43.

14. Tüzüner $S$, Aydin AT. Arthroscopic removal of an osteoid osteoma at the talar neck. Arthroscopy. 1998;14(4):405-9. 